\title{
Ergonomics of anatomical bra models for breastfeeding: a contribution of nursing
}

\author{
Ergonomia de modelos anatômicos de sutiã para amamentação: uma contribuição da enfermagem
}

Ergonomía de modelos anatómicos de sostén para lactancia materna: una contribución de la enfermería

$\begin{array}{r}\hline \text { Anita Batista dos Santos Heberle' } \\ \text { ORCID: 0000-0002-5723-7047 } \\ \text { Alexandrina Aparecida Maciel Cardelli" } \\ \text { ORCID: 0000-0002-0222-8821 } \\ \text { leda Harumi Higarashi' } \\ \text { ORCID: 0000-0002-4205-6841 } \\ \text { Maria Dalva de Barros Carvalho' } \\ \text { ORCID: 0000-0002-1377-3331 } \\ \text { Percy Nohama'"' } \\ \text { ORCID: 0000-0002-8051-8453 } \\ \text { Sandra Marisa Pelloso' } \\ \text { ORCID: 0000-0001-8455-6839 } \\ \hline\end{array}$

'Universidade Estadual de Maringá. Maringá, Paraná, Brazil. "Universidade Estadual de Londrina. Londrina, Paraná, Brazil. I'Pontifícia Universidade Católica do Paraná. Curitiba, Paraná,

Brazil.

How to cite this article: Heberle ABS, Cardelli AAM, Igarashi IH, Carvalho MDB Nohama P, Pelloso SM. Ergonomics of anatomical bra models for breastfeeding: a contribution of nursing.

Rev Bras Enferm. 2022;75(3):e20210264. https://doi.org/10.1590/0034-7167-2021-0264

Corresponding author:

Anita Batista dos Santos Heberle

E-mail: absheberle@uem.br

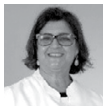

EDITOR IN CHIEF: Álvaro Sousa ASSOCIATE EDITOR: Fátima Helena Espírito Santo

\section{ABSTRACT}

Objectives: to analyze the ergonomics of two models of breastfeeding bras. Methods: descriptive study carried out with 152 infants in a Brazilian university hospital. The prototypes were separated into two groups ( $A$ and $B$ ). To compare the two bra models, the Odds Ratio $(\mathrm{OR})$ was used as a measure of the strength of the association. In subjective perceptions, the Modified Borg Scale, and the chi-square test of independence (x2) were used. To compare the two prototypes, the $Z$ test and logistic regression analysis were performed. A significance level of $5 \%$ was considered. Results: the bra in group B was more suitable for ergonomics of physical and psycho-aesthetic comfort than the bra in group A ( $p<0.0001)$, according to the logistic regression tests. Conclusions: modeling $B$ was ergonomically adequate, with usability and evaluation criteria centered on breastfeeding women.

Descriptors: Nursing; Breast Feeding; Ergonomics; Models Anatomic; Postpartum Period.

\section{RESUMO}

Objetivos: analisar a ergonomia de duas modelagens de sutiãs para amamentação. Métodos: estudo descritivo realizado com 152 lactantes em um hospital universitário brasileiro. Os protótipos foram separados em dois grupos (A e B). Para comparar as duas modelagens de sutiãs, foi utilizado a Odds Ratio (OR) como uma medida de intensidade da associação. Nas percepções subjetivas, utilizaramse a Escala de Borg Modificada e o teste qui-quadrado de independência $\left(\mathrm{X}^{2}\right)$. Para comparar os dois protótipos, realizou-se o teste $Z$ e análise de regressão logística. Considerou-se um nível de significância de $5 \%$. Resultados: o sutiã do grupo $B$ foi o mais adequado para ergonomia de conforto físico e psicoestético do que o do grupo $\mathrm{A}(p<0,0001)$, segundo os testes de regressão logística. Conclusões: a modelagem B foi ergonomicamente adequada, com critérios de usabilidade e avaliação centrada nas lactantes. Descritores: Enfermagem; Aleitamento Materno; Ergonomia; Modelos Anatômicos; Período PósParto.

\section{RESUMEN}

Objetivos: analizar la ergonomía de dos modelados de sostén para lactancia materna. Métodos: estudio descriptivo realizado con 152 lactantes en un hospital universitario brasileño. Los prototipos fueron separados en dos grupos (A y B). Para comparar los dos modelados de sostén, fue utilizado la Odds Ratio (OR) como una medida de intensidad de la asociación. En las percepciones subjetivas, se utilizaron la Escala de Borg Modificada y el test chi-cuadrado de independencia $\left(\mathrm{X}^{2}\right)$. Para comparar los dos prototipos, se realizó el test Zy análisis de regresión logística. Se consideró un nivel de significación de $5 \%$. Resultados: el sostén del grupo $B$ fue el más adecuado para ergonomía de conforto físico y psicoestético del que el del grupo $\mathrm{A}(p<0,0001)$, segundo los testes de regresión logística. Conclusiones: el modelado $B$ fue ergonómicamente adecuado, con criterios de usabilidad y evaluación centrada en las lactantes.

Descriptores: Enfermería; Lactancia Materna; Ergonomía; Modelos Anatómicos; Periodo Posparto. 


\section{INTRODUCTION}

Breastfeeding is one of the most important practices in a woman's life because of the benefits it brings to both the mother and the baby. Breast milk has excellent properties and can prevent many diseases. Worldwide, less than $40 \%$ of children are exclusively breastfed in the first six months of life. In recent years, breastfeeding rates have stagnated in some countries, which has made it difficult to reach the global goal of achieving $50 \%$ exclusive breastfeeding by $2015^{(1)}$, an action that would reduce maternal, newborn and child mortality ${ }^{(2)}$.

The encouragement of breastfeeding and consequently, its increased could prevent more than 823 thousand deaths of children under 1 year and 20 thousand deaths of women with breast cancer ${ }^{(3)}$. In this context, there is a need for actions involving health professionals, aiming to increase breastfeeding rates ${ }^{(4)}$.

Several aspects are responsible for the failure of breastfeeding, including sociocultural and environmental factors, beliefs, and physiological difficulties. During the practice of breastfeeding, women may encounter problems in the physiology of lactation, breasts that produce more milk than the child demands, becoming full, tense and painful, and lack of knowledge and actions to minimize these problems ${ }^{(5)}$.

Researchers have suggested the use of technology to minimize problems with the breasts, and support through a bra that provides comfort is an appropriate measure in this process ${ }^{(6)}$.

Currently, inappropriate bras seem to harm women's health, with negative outcomes - headaches, back pain and postural problems - which limit physical activities, compromising quality of life, especially for those with large breasts ${ }^{(7)}$.

During breastfeeding, tight bras interfere with the flow of milk and can cause obstruction of the lactiferous ducts. The fabric of this piece should have a soft, non-abrasive feel, with good absorption of milk fluids. On the one hand, inadequate material can aggravate nipple injuries, so proper clothing is a health issue ${ }^{(6)}$. On the other hand, there are new technologies in the textile industry that interact with the organism, whose effects and benefits have already been recognized ${ }^{(8)}$. The breastfeeding bra is a piece that provides support for the breasts and should be in harmony with the breastfeeding woman's body ${ }^{(6)}$.

In recent years, ergonomics has gained attention, being considered in the projection of various products given its relevance in the user's perception. Although ergonomics and comfort have been parameters in product development, the methodology for analyzing user activity is not yet universally consolidated ${ }^{(9)}$.

Authors emphasize the importance of this analysis with the user $^{(10)}$ from the perspective of usability and comfort ${ }^{(11)}$, especially with regard to anthropometry in the area of clothing ${ }^{(10)}$. On the other hand, usability, as part of ergonomics ${ }^{(11)}$, is conceptualized for its effectiveness, efficiency and satisfaction in a context of particular use, in which satisfaction is defined by the absence of discomfort, including the positive aspects in relation to the product $^{(12)}$. Thus, anthropometry (body measurement) has been applied in product designs with a relevant role in ergonomics, due to aspects related to comfort. A well-developed product will perform better ${ }^{(13)}$, and anthropometric data will only be of importance for ergonomics if analyzed from the user's perspective ${ }^{(14)}$.
Researchers have promoted reflections on the principles of universal design related to fashion and clothing products ${ }^{(11)}$. There are still many challenges in standardizing measurements, especially for bras, due to the diversity of shapes and sizes that involve the mammary gland ${ }^{(15)}$. A study in the United Kingdom found that the traditional method used in assembling bras was considered inadequate, particularly for women with large breasts ${ }^{(10)}$.

It is recommended, in the postpartum pregnancy period, the use of bras that provide good support for the breasts. In daily practice, it is observed that lactating women have used various inappropriate models of bras, with negative outcomes in the breastfeeding process, which includes breast engorgement. Thus, to meet these demands, nurses have sought interdisciplinarity from the perspective of comprehensive care. Thus, it is important to ergonomically analyze which bra model is the most suitable, also including new technologies in the textile industry in the manufacture of "smart fabrics", that is, those that rely on the application of nanotechnology.

\section{OBJECTIVES}

To analyze the ergonomics and usability of two models of breastfeeding bras.

\section{METHODS}

\section{Ethical aspects}

The research was approved by the research ethics committee (REC) with human beings of the state university of Maringá, in compliance with the determination of Resolution $n^{\circ} 466 / 12$ of the national health council. After explaining the research objectives, the participants formalized their acceptance to participate by signing the informed consent form.

\section{Study design, period, and place}

Descriptive study, with a quantitative approach, carried out in the Rooming-in of a public teaching hospital in southern Brazil, from August 1, 2016 until March 30, 2018. For the methodological conduct of the study, the guidelines of the EQUATOR through Strengthening The Reporting of Observational Studies in Epidemiology (STROBE).

\section{Population and sample}

The study was carried out with a single group of infants using two models of bras.

To calculate the sample, the hypothesis was adopted that one of the bra models would present a $60 \%$ preference over the other, a significance level of $5 \%$ and a test power of $80 \%$. This resulted in a random sampling of 152 infants to evaluate two groups of bras (prototype A and prototype B), so that both bra models had the same chance of being used on the first day.

\section{Inclusion and Exclusion Criteria}

Breastfeeding women aged 18 years or over, between the 1st and 2 nd day of the puerperium, with an established lactation 
process and bra numbering between 40 and 46, were included. Postpartum women with multiple births who, for some reason, were not breastfeeding; and those diagnosed with breast cancer were excluded.

\section{Study protocol}

A nurse with experience in breastfeeding performed data collection with the women recruited during the hospitalization period. The lactating women were invited to participate in the study on the first day of the puerperium, when the inclusion and exclusion criteria were evaluated; then the two models of bras were received to be evaluated.

For the use of the two models of bras, the prototypes were divided into two groups (prototype $A$ and prototype B) duly identified. A systematic random draw was performed to define which bra model the lactating woman would wear on the first day. Thus, the two models of bras had the same chance of being evaluated on the first day of intervention. The pieces remained with the lactating women for a period of two days. They were instructed on which model would be initially evaluated (by drawing lots), with instruction that each model was used for 24 hours, and that the respective evaluation questionnaire was answered soon after using each model.

For this study, two structured scripts for the interview were created. The materials used were 20 bras prototypes ( 10 of each model), consisting of a 6.6 polyamide fiber called Emana', in black color (Figure 1). This material was chosen because it is considered efficient and innovative. Its bioactive crystals, incorporated in the polymer matrix, work as infrared, capable of interacting with the body, transforming the heat emitted by the body into energy, with great benefits to people's health ${ }^{(8)}$. The black color was adopted as it is the only one available in the local market. It is noteworthy that the bras received a domestic washing process with liquid detergent for delicate clothes before being offered to the next nursing mother. This process was considered adequate because, according to the manufacturer's information, this fiber does not lose its characteristics, even after infinite washings.

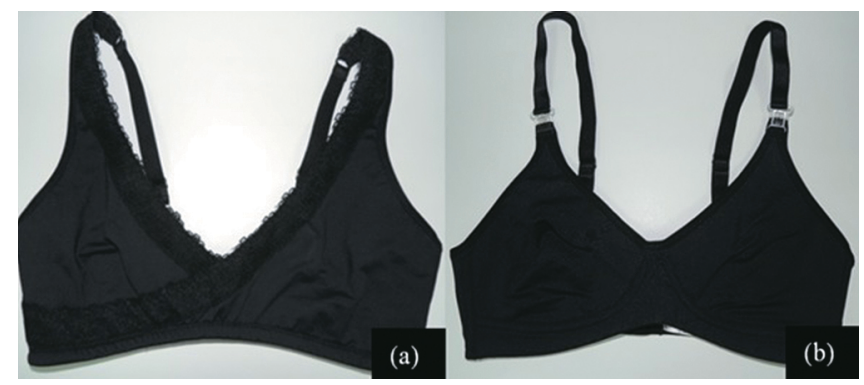

Figure 1 - Breastfeeding bra models. In (a) modeling with transfixed bulge, seamless and without thermal molding (prototype A). In (b) traditional modeling, seamless bulge, and thermal molding (prototype $B$ )

For the present study, it was considered that the bra models to be evaluated should have physical ergonomics and comfort wearability characteristics as fundamental components for the promotion and support of breastfeeding, and that they should be comfortable and economical materials. Thus, supposedly functional bras were adopted, aiming at the satisfaction related to the physical and psycho-aesthetic comfort of the lactating women. Modeling A was composed of pierced bulges, including a lace detail, providing delicacy to the lingerie. Model B was a bra with a design closer to the traditional models and also included a lace detail. The usability concept of the International Organization for Standardization (ISO 9241-11:1998) ${ }^{(12)}$ and the recommendations of the Brazilian Association of Technical Standards (ABNT - NBR 13377) ${ }^{(16)}$ were adopted. The context of bra use, the task of breastfeeding and the physical and social environment of the lactating women were also considered.

The independent variables were: age $(18-25,26-34$ and $\geq$ 35 years old); education ( $<8$ years of study, $\geq 8$ years of study); dummy number (40, 42, 44 and 46); style (traditional, modern, romantic, others); fabric preference for underwear (plain, printed); type of print (polka dots, floral, others); two bra models (prototype $A$ and prototype $B$ ). The ergonomic dependent variables were: discomfort when dressing; discomfort when withdrawing; discomfort during breastfeeding; discomfort in contact with tissue; discomfort in breast support. The usability variables were: first impression when seeing the bra (aesthetics - apparent usability); cup temperature; if the bra got out of place when the nursing mother raised her arms; seam marks on the skin; removal of the sleeping bra; items that could be improved (handle, material, others); intention of use (if you would buy such a model).

Discomfort perceptions were assessed using the Modified Borg Scale, which is a scale for the assessment of subjective perceptions of exertion. Borg's CR10 (Category-Ratio Scale) is one of the versions that has ten intensity categories. This scale has paired ratios and categories, where each category has a continuous numerical value. Anchored in this classification, the subject judges the discomfort, associating it with a verbal category, attributed to a numerical score ( 0 - absolutely nothing; 0.5 - extremely weak; 1 - very weak; 2 - weak; 3 - moderate; 4 - moderate/strong; 5 and 6 - strong; 7, 8 and 9 - very strong; and 10 - extremely strong ${ }^{(17)}$. This scale was selected because it is a translated and validated instrument for use in Brazil(18).

\section{Analysis of results and statistics}

Data were stored in the Microsoft Office Excel $2010^{\circ}$ program; and, for descriptive statistical analysis, absolute and relative frequency tables were used, and all analyzes, both descriptive and inferential, were performed using the R software.

To compare the two models of bras, OR was used as a measure of the strength of the association between the prototypes (group A and group B). In order to compare the proportions, that is, the possible divergences between the observed frequencies of the qualitative variables, grade assignments were adopted using the Modified Borg Scale. In this analysis, the chi-square test of independence $(x 2)$ was used for each question individually, in order to verify the existence of a possible relationship between the two models of bras. To identify whether there was a significant difference between the prototypes $(A ; B)$, the $Z$ test and logistic regression analysis were performed. In all tests, a significance level of $5 \%$ was considered. 


\section{RESULTS}

Among the lactating women studied, $65.8 \%$ were aged between 18 and 25 years; $65.1 \%$, education $\geq 8$ years. As for bra size, $15.8 \%$ wore a dummy $40 ; 23.7 \%$, dummy $42 ; 44.7 \%$, dummy 44 ; and $15.8 \%, 46$. Regarding the usability of underwear, $52 \%$ of the lactating women considered themselves to be of traditional style, $55.9 \%$ suggested prints ( $n=85$ ). Among the latter, $29.4 \%$ like the dot; $25.9 \%$ prefer floral, and $44.7 \%$ suggested other prints or did not want to say.

In the present study, prototype A and prototype B were used to verify the ergonomics and usability of two models of breastfeeding bras. Thus, the subjective perceptions of breastfeeding women were included. In this analysis, grade assignments were used, and the Modified Borg Scale was applied, which allowed the association of each numerical value to the verbal categories. Thus, the scale was recategorized into two perceptions, one related to no discomfort (score 0 ) and the other to some discomfort (score greater than 0 ). Seven contingency tables were obtained; for this, the $x 2$ test was performed for each question individually, in order to verify the existence of a possible relationship between the two models of bras (A; B) (Figure 2).

Questions 1, 2, 3 and 4 showed that, for prototype $A$, more lactating women felt uncomfortable; on the other hand, with prototype $B$, most lactating women did not feel any discomfort, as they indicated a score of 0 . For these questions, the $p$ values of the $x 2$ test were equal to or less than $0.001(<0.001 ;<0.001 ; 0.001 ;<0.001$, respectively). Questions 5, 6 and 7 showed strong evidence that prototypes $A$ and $B$ do not exert any influence on the grades. It can be seen, in Figure 2, that the values are similar for the two prototypes. This was confirmed through the $p$ values of the $x 2$ test, which were greater than $5 \%(0.422 ; 0.856 ; 0.080$, respectively).

In the present study, the two models of bras were evaluated in order to identify any usability problems based on ergonomic comfort criteria. A $\times 2$ test was performed for each question presented, in order to observe whether there was a significant difference between the two prototypes. The results are shown in Figure 3.

In Figure 3, the variables "got out of place when arms were raised" and "took it off to sleep" presented usability problems in prototype $A$, showing a significant difference in the $x 2$ test $(p<0.001)$, when compared to prototype B. In relation to the variable "marked the skin", both showed similar performance $(p=0.722)$, with no significant difference between the two models. As for the improvements, group A had modeling as the most suggested item, while group $B$ had the handles as the most indicated item.

Women were asked about their intended use in future lactation. To identify whether there was a significant difference between the prototypes $(A ; B)$, the $Z$ test and logistic regression analysis were performed for the variables "Would use" and "Would not use" (Table 1).

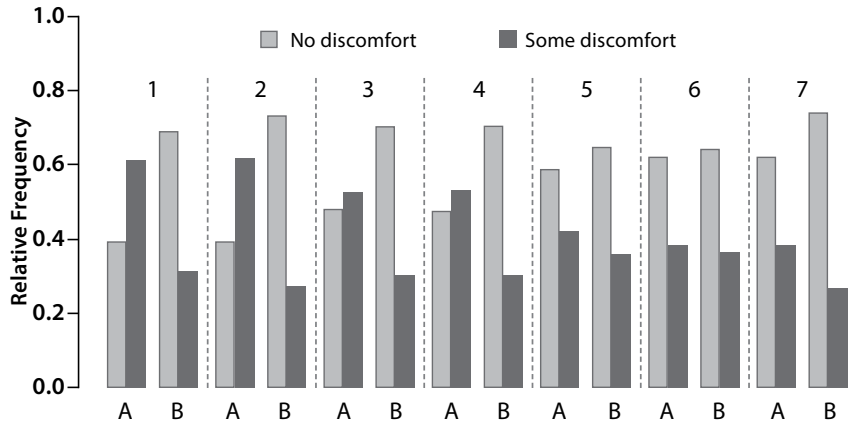

Figure 2 - Frequency relative to prototypes $A$ and $B$, for each question related to perception. The Borg scale was recategorized into two groups, one related to lactating women who did not feel any discomfort (score 0 ) and the other to the other categories. The numbering above the bars denotes the questions: 1 is the "first impression"; 2 , "discomfort wearing it"; 3 , "discomfort when taking it off"; 4 , "discomfort to breastfeed", 5 , "discomfort in contact with the skin", 6, "discomfort with the temperature of the cup"; and 7, "breast support"
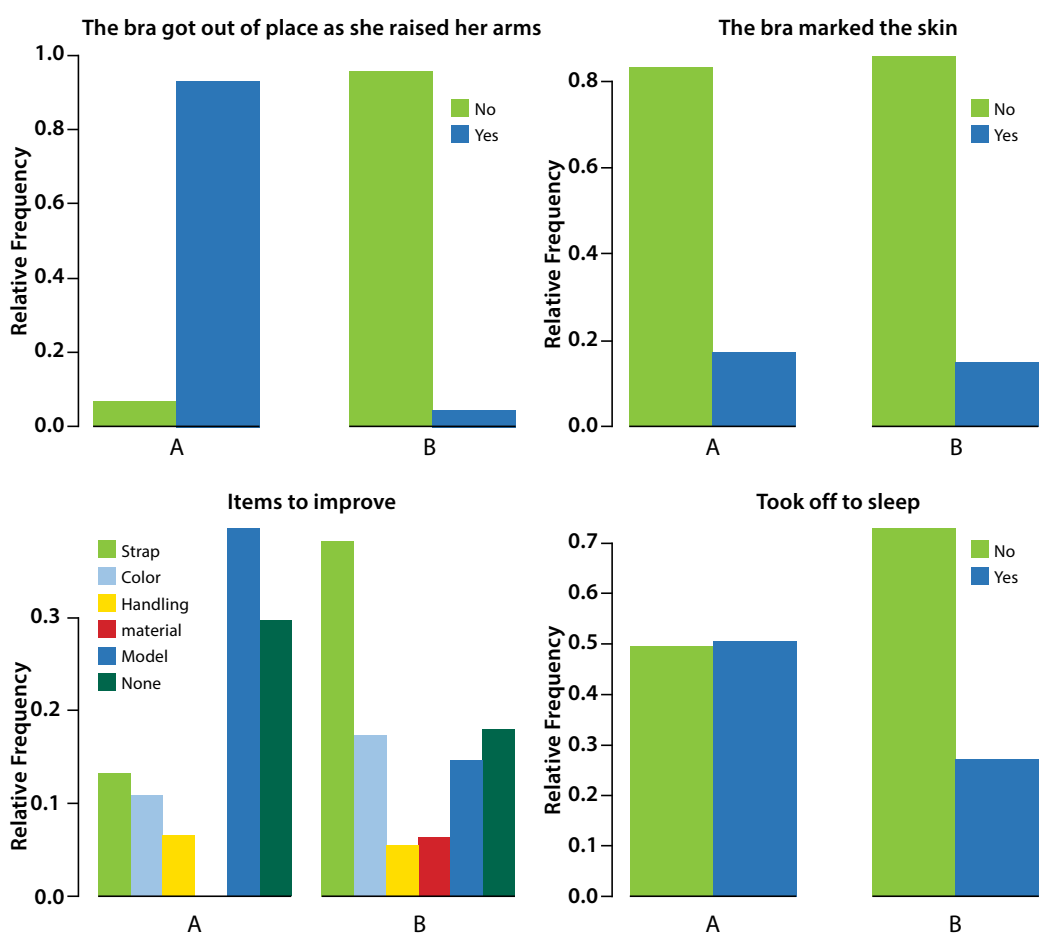

Took off to sleep
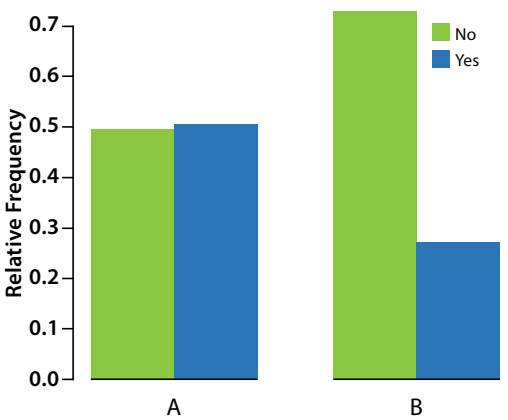

the skin", "Items to improve" and "Took off to sleep"

Table 1 - Distribution of infants according to the intention to use the prototypes in a future lactation, Maringá, Paraná, Brazil, 2018

\begin{tabular}{|c|c|c|c|c|c|}
\hline \multirow{3}{*}{ Resposta } & \multicolumn{4}{|c|}{ Prototype } & \multirow{3}{*}{$p$} \\
\hline & \multicolumn{2}{|c|}{$\begin{array}{c}A \\
(n=152)\end{array}$} & \multicolumn{2}{|c|}{$\begin{array}{c}B \\
(n=152)\end{array}$} & \\
\hline & $\mathbf{n}$ & $\%$ & n & $\%$ & \\
\hline Would use & 66 & 43.4 & 103 & 67.8 & $0.0001^{*}$ \\
\hline Would not use & 86 & 56.6 & 49 & 32.2 & $0.0001^{*}$ \\
\hline
\end{tabular}

*Significant $Z$ test considering a significance level of $5 \%$.

It is observed in Table 1 that there is evidence of greater acceptance of prototype $B$ when compared to prototype $A(p<0.0001)$. 
To identify whether there really was a significant difference between the prototypes $(A ; B)$, logistic regression analysis was performed for the variables "Use it" and "Would not use it". This important data, although not presented in a table, shows that there is greater acceptance of prototype $B$ when compared to prototype A $(p<0.001)$. The preference for prototype $B$ was three times greater $(95 \% \mathrm{Cl}: 1.826 ; 4.709)$ than for prototype A.

\section{DISCUSSION}

In daily practice during the postpartum pregnancy period, the use of bras that provide good support for the breasts is recommended. However, it has been observed that lactating women have used various models of bras, including those that impair milk flow by obstructing the ducts, which causes mastitis and poses a risk to the health of the breasts. However, at least two models seem suitable for lactating women. One has a traditional modeling, a seamless cup with thermal molding, which favors the anatomy of the breast. The other has a simple style, looks practical, seamless bulge, also with thermal molding. Thus, it was important to compare the two models to identify which one would be ergonomically adequate, including new technologies in the textile industry. Thus, we sought to identify an ergonomically adequate breastfeeding bra modeling, with usability and satisfaction criteria in the aspects of physical and psycho-aesthetic comfort, thus representing a contribution of nursing research in favor of breastfeeding.

In this study, therefore, there was the hypothesis that one of the two proposed models would present a higher percentage of preference among the lactating women studied (due to the evaluation tests) and that one of them would have greater ergonomic and usability characteristics.

The style preference for the use of underwear was traditional. However, the vast majority suggested including printed fabric when making the nursing bra, and the most preferred prints were polka dot and floral. For this variable studied, there was no recent study in the literature that could bring data for such discussion.

In this study, other variables were analyzed in both models, with the purpose of evaluating subjective perceptions and identifying the positive points that promoted satisfaction, in addition to the negative aspects that caused discomfort and dissatisfaction to breastfeeding women. The lowest grades were attributed to modeling $A$, in which the breastfeeding women felt uncomfortable in relation to aesthetics, time to dress, withdraw and breastfeed. For modeling $B$, these aspects were considered positive, providing greater comfort and satisfaction.

Underwear fashion has its meanings and attributions, which are not linked only with the protective function. Thus, it has been increasingly concerned with the needs of breastfeeding women. Generally, this audience only finds functional pieces, that is, they leave aesthetics in the background. However, there is a percentage of these women who still seek to satisfy their psycho-aesthetic needs, that is, they also seek to expose their feelings when wearing the garment. Breastfeeding is a delicate phase, in which women deal with complex situations involving physical and psychological factors, needing support and encouragement to restore their feelings ${ }^{(19)}$.
In this study, although model A presented a practical model, with details in lace, providing delicacy to the garment, this prototype obtained a high failure rate. This indicates that, in the postpartum pregnancy cycle, women are not only seeking physical comfort, or support for their breasts, but also to feel beautiful. In this context, the contact of the piece with the user's body provokes sensory responses, including psychological comfort ${ }^{(20)}$. This situation was also observed in another study with bra for sports activities, in which lactating women expressed the desire to feel attractive. They reported that their clothes make them look ugly during pregnancy and postpartum and that they would like to feel beautiful, with high self-esteem. From this perspective, researchers can meet these demands based on ideas and suggestions from users ${ }^{(6)}$.

In the activities of dressing, withdrawing, and breastfeeding, modeling $A$ also performed less well when compared to modeling B. In a study on sports bras carried out with marathon runners ${ }^{(21)}$, they found that $49 \%$ of them classified their bra as inappropriate. Although half of the volunteers gave grades of 9 or 10 to their bras, $75 \%$ of them verbalized problems in adapting this piece, generating dissatisfaction for the users. This dissatisfaction can be explained by the lack of interaction between bra models and the anatomical diversity of the female body. Supposedly, the physical discomfort caused by the bra's inadequacy to the user's needs may also include the incorrect use of materials ${ }^{(21)}$. Some authors ${ }^{(20)}$ explain that many industries focus on modeling diversity in order to meet different demands, such as "fitting the part into the body". The industry has been improving its technologies and production systems, but there is still a gap between ergonomics, usability, and the quality of underwear.

In the analyzes on skin contact, temperature and support for the breasts, there was no significant difference between the proposed models. This can be explained because both prototypes were made of the same textile fiber, with the same physical and chemical characteristics. Thus, they were made from materials resulting from the application of new technologies in the textile industry. In the present study, to promote tactile comfort, a tissue considered soft, delicate, with rapid absorption of lactic fluids was selected to prevent the proliferation of microorganisms. It is noteworthy that lactating women with nipple trauma were allowed to wear a nipple shield.

Regarding tactile comfort, in a study with a breastfeeding bra, lactating women reported that non-abrasive tissues provide greater comfort to the nipples ${ }^{(6)}$. Regarding microorganisms, the same authors report that the main problems in breastfeeding are nipple lesions and breast infections. For other authors ${ }^{(22),}$ cotton clothes are an ideal culture medium for microorganisms, because the temperature and humidity associated with dead skin cells and other cutaneous excretions create a favorable environment for the proliferation of bacteria and fungi. Thus, pathogens present on the surface of tissue fibers pose health risks. Likewise, some authors ${ }^{(21)}$ draw attention to thermal properties and proper fit as important factors in the making of a bra, considering women's satisfaction and breast health.

In this study, some variables were analyzed to identify usability problems based on ergonomic and comfort criteria. It 
was observed that, in both models, there was some kind of discomfort. Model A presented a greater usability problem in the variables "out of place", "to go to sleep". The vast majority did not report a skin mark in both models, with no statistical difference between them. As for the variable "items to improve", it was suggested to improve modeling model A, that is, the participants were not satisfied with the model in general. In modeling $B$, although it already had wider straps than the traditional ones, this was the item suggested for improving the bra, which is in line with another study ${ }^{(6)}$, in which wide straps were also suggested by breastfeeding women for sports bras . In another study ${ }^{(20)}, 51.4 \%$ of women said they could not find bras that fit properly to the breasts and back.

In this research, it was observed that both proposed models were rejected by the lactating women at the time of evaluation: many women evaluated only one prototype for psycho-aesthetic reasons. However, lactating women were not excluded from the study because this fact was not foreseen in the exclusion criteria and also because the non-acceptance of the model could represent important information in the comfort usability tests. All lactating women who rejected any of the models claimed that they did not evaluate prototype $A$ or $B$ for aesthetic reasons. In different cultures, breasts represent femininity, motherhood, and sexuality. Thus, psychological comfort is an important aspect for the well-being and self-esteem of women ${ }^{(23)}$. Likewise, clothing plays an important role in the lactation period. Infants need to feel comfortable when they breastfeed with others; thus, clothing cannot represent a negative aspect in this process ${ }^{(6)}$.

In Brazil, nursing research involving other areas of knowledge is still limited ${ }^{(24)}$ - not covering sectors such as the textile industry. The latter has used new technologies, such as polyamide 6.6 fibers, to make clothes that increase body temperature and microcirculation $^{(8)}$. Therefore, it seemed pertinent to know the perceptions of lactating women in relation to this tissue, considering the physiological aspects of the breast during lactation. On the other hand, considering the problems faced by women in breastfeeding, it is necessary to adopt comfort measures ${ }^{(6)}$.

Among the lactating women in this study, more than half were considered to be of great age ( 18 and 25 years), as older age is considered unfavorable to breastfeeding, as lactating women tend to be more committed than before to professional stability, which can generate unavailability of time for child care $^{(25)}$. However, older women manifest greater intention to breastfeed when compared to younger women ${ }^{(26)}$.

In this study, most lactating women had eight years of schooling or more. Another study ${ }^{(27)}$ showed that less than high school education negatively influenced breastfeeding, reducing the prevalence of non-breastfeeding by $17 \%$. It is considered that women with higher education have greater knowledge about breastfeeding ${ }^{(25)}$ and greater understanding of its benefits ${ }^{(26)}$.

It was observed that almost half of them used a size 44 mannequin; many stated that they had not yet purchased a nursing bra, and some were dissatisfied with their body image. This fact can be explained by the increase in weight during pregnancy and the uncertainty regarding the size of the bra during the lactation period. Infants increase their bra size by at least one number after delivery ${ }^{(6)}$. On the other hand, bra size has been a reason for dissatisfaction among women in Brazil. A study showed that, in more than half of the sample, users reported difficulties in finding bras sizes that are adequate and comfortable ${ }^{(20)}$. With regard to weight during pregnancy, studies have revealed that concern with self-image is a risk factor for postpartum depression ${ }^{(28)}$. Another recent study showed obesity, greater weight gain and body dissatisfaction as factors that negatively influence breastfeeding ${ }^{(29)}$, with impacts on the health of mother and child ${ }^{(28)}$.

In the present study, the bras evaluated were made using a new polyamide 6.6 available on the market, observing aspects of ergonomics and usability in its use in nursing mothers. However, as it is considered an "intelligent tissue", further studies and the application of a different methodological approach to the evaluation of possible clinical effects on human lactation are needed.

\section{Study limitations}

The development of the study in a single public institution was a limitation. The inclusion of other public and private institutions could present a differentiated lactating population.

\section{Contributions to the field of Nursing}

Nurses must be involved in an interdisciplinary way and include other areas of knowledge, especially in research, seeking evidence to support their practice. He is considered the health professional most involved with the practice of breastfeeding and is faced with situations in which an ergonomically adequate bra can avoid the elbowing of the breast ducts, protecting the breastfeeding woman from events that can interfere with breastfeeding, including breast engorgement and mastitis.

\section{CONCLUSIONS}

In this interdisciplinary study involving nursing, group B bra modeling obtained greater comfort attributions with a statistically significant difference between the two proposed models. They were also considered comfortable in contact with the skin and adequate regarding the temperature of the bulge and breast support, justifying the use of the same textile fiber in both bra models. The modeling was approved based on an assessment centered on the actual needs of breastfeeding women/users and needs to have its prototype implemented. The ergonomically adequate nursing bra, with usability and satisfaction criteria in terms of physical and psycho-aesthetic comfort for nursing mothers, has traditional modeling, seamless cup, with thermal molding and wider straps than the traditional ones, including a lace detail to add delicacy the piece.

\section{ACKNOWLEDGMENT}

The Authors are grateful to the lactating women main protagonists of this research. They were companions and generous in the most important moment of their lives. 


\section{REFERENCES}

1. World Health Organization. Global nutrition targets 2025: policy brief series [Internet]. Geneva: WHO; 2014 [cited 2018 Jun 07]. Available from: http://apps.who.int/iris/bitstream/handle/10665/149018/WHO_NMH_NHD_14.2_eng.pdf?sequence=1

2. Al-Nuaimi N, Katende G, Arulappan J. Breastfeeding trends and determinants: implications and recommendations for gulf cooperation council countries. Sultan Qaboos Univ Med J. 2017;17(2):e155-61. https://doi.org/10.18295/squmj.2016.17.02.004

3. Victora CG, Bahl R, Barros AJD, França GVA, Horton S, Krasevec J, et al. Breastfeeding in the 21st century: epidemiology, mechanisms, and lifelong effect. Lancet. 2016;387(10017):475-90. https://doi.org/10.1016/S0140-6736(15)01024-7

4. Heberle ABS, Nohama P, Pelloso SM. Evaluation of the puerperal breast through thermography: a case report. Cogitare Enferm. 2019;24:e57569. https://doi.org/10.5380/ce.v24i0.57569

5. Ayed AAN. Knowledge, attitude and practice regarding exclusive breastfeeding among mothers attending primary health care centers in Abha city. Int J Med Sci Public Health. 2014;3(11):1355-63. https://doi.org/10.5455/ijmsph.2014.140820141

6. Morris K, Park J, Sarkar A. Development of a nursing sports bra for physically active breastfeeding women through user-centered design. Cloth Text Res J. 2017;35(4):290-306. https://doi.org/10.1177/0887302X17722858

7. Coltman CE, Steele JR, McGhee DE. Breast volume is affected by body mass index but not age. Ergonomics. 2017;60(11):1576-85. https://doi. org/10.1080/00140139.2017.1330968

8. Kertmen N. New trends in fibers used in denim fabric production. J Tex Eng. 2021;28(121):48-59. https//doi.org/10.7216/1300759920212812106

9. Souza JBG, Menegon NL, Sticca MG, Rossi TN. Parameters related to passengers' comfort: a research on the practices adopted by seat manufacturers. Prod. 2013;23(1):157-67. https//doi.org/10.1590/S0103-65132012005000004

10. White J, Scurr J. Evaluation of professional bra fitting criteria for bra selection and fitting in the UK. Ergonomics. 2012;55(6):704-11. https// doi.org/10.1080/00140139.2011.647096

11. Martins SB, Martins LB. Ergonomics, design universal and fashion. Work. 2012;41(suppl 1):4733-38. https//doi.org/10.3233/ WOR-2012-0761-4733

12. International Organization for Standardization. ISO 9241-11:1998. Ergonomic requirements for office work with visual display terminals (VDTs): part 11: guidance on usability [Internet]. Geneva: ISO; 1998[cited 2020 Mar 03]. Available from: https://www.iso.org/obp/ ui/\#iso:std:iso:9241:-11:ed-1:v1:en

13. Ahn SH, Kwon S, Bahn S, Yun MH, Yu W. Effects of grip curvature and hand anthropometry for the unimanual operation of touchscreen handheld devices. Hum Factor Ergon Manuf Serv Ind. 2016;26(3):367-80. https//doi.org/10.1002/hfm.20662

14. Rodriguez-Añez CR. A antropometria e sua aplicação na ergonomia. Rev Bras Cineantropom Desempenho Hum. 2001;3(1):102-8. https:// doi.org/10.1590/\%25x

15. Bengtson BP, Glicksman CA. The standardization of bra cup measurements: redefining bra sizing language. Clin Plast Surg. 2015;42(4):40511. https//doi.org/10.1016/j.cps.2015.06.002

16. Associação Brasileira de Normas Técnicas. NBR 13377: medidas do corpo humano para vestuário: padrões referenciais [Internet]. Rio de Janeiro: ABNT; 1995[cited 2020 Mar 03]. Available from: https://idoc.pub/documents/ nbr-13377-medidas-do-corpo-humano-para-vestuario-padroes-is-pon26vyr63I0

17. Borg G. Borg's perceived exertion and pain scales. Champaign (IL): Human Kinetics; 1998.

18. Villar R, Gillis J, Santana G, Pinheiro DS, Almeida ALRA. Association between anaerobic metabolic demands during simulated Brazilian jiu-jitsu combat and specific jiu-jitsu anaerobic performance test. J Strength Cond Res. 2018;32(2):432-40. https//doi.org/10.1519/ JSC.0000000000001536

19. Kariya $A B, O$ consumidor e a moda: a aplicação da cocriação no desenvolvimento de peças underwear [Dissertação]. Apucarana (PR): Universidade Tecnológica Federal do Paraná; 2017.

20. Neves EP, Brigatto AC, Paschoarelli LC. Moda íntima: uma abordagem acerca dos aspectos de usabilidade. Hum Factors Des [Internet]. 2015[cited 2020 Mar 03];4(8):58-75. Available from: https://www.revistas.udesc.br/index.php/hfd/article/view/6656

21. Brown N, White J, Brasher A, Scurr J. An investigation into breast support and sports bra use in female runners of the 2012 London marathon. J Sports Sci. 2014;32(9):801-9. https//doi.org/10.1080/02640414.2013.844348

22. Zhang YY, Xu QB, Fu FY, Liu XD. Durable antimicrobial cotton textiles modified with inorganic nanoparticles.Cellulose. 2016;23:2791-808. https//doi.org/10.1007/s10570-016-1012-0

23. Guimarães PAMP, Resende VCL, Sabino Neto M, Seito CL, Brito MJA, Abla LEF, et al. Sexuality in aesthetic breast surgery. Aesthetic Plast Surg. 2015;39(6):993-9. https//doi.org/10.1007/s00266-015-0574-9

24. Oliveira BGRB, Erdmann AL, Fuly PSC, Oliveira AP, Rodrigues ALS. Wound care research groups registered in Brazil: a transversal study. Online Braz J Nurs. 2013;12(2):307-18. https://doi.org/10.5935/1676-4285.20133988 
25. Rieth NFA, Coimbra LC. Caracterização do aleitamento materno em São Luís, Maranhão. Rev Pesqui Saude [Internet]. 2016 [cited 2020 Mar 03];17(1):7-12. Available from: http://www.periodicoseletronicos.ufma.br/index.php/revistahuufma/article/view/5487/3360

26. Vieira TO, Martins CC, Santana GS, Vieira GO, Silva LR. Maternal intention to breastfeed: a systematic review. Cienc Saude Colet. 2016;21(12):3845-58. https//doi.org/10.1590/1413-812320152112.17962015

27. Rigotti RR, Oliveira MIC, Boccolini CS. Association between the use of a baby's bottle and pacifier and the absence of breastfeeding in the second six months of life. Cienc Saude Colet. 2015;20(4):1235-44. https//doi.org/10.1590/1413-81232015204.00782014

28. Meireles JFF, Neves CM, Carvalho PHB, Ferreira MEC. Imagem corporal de gestantes: um estudo longitudinal. J Bras Psiquiatr. 2016;65(3):22330. https//doi.org/10.1590/0047-2085000000128

29. Swanson V, Keely A, Denison FC. Does body image influence the relationship between body weight and breastfeeding maintenance in new mothers?. Br J Health Psychol. 2017;22(3):557-76. https//doi.org/10.1111/bjhp.12246 